\title{
Money in the poetic universe of Pernambuco's Zona da Mata region
}

Simone Silva

\begin{abstract}
This article looks to present the various meanings given by people to money in the cantoria de pé-de-parede, a meeting organized at home or in a bar by a family head or the owner of the commercial establishment to hear verses improvised by a duo of poet-singers. Through the ethnographic material, the text examines the categories used to designate money and the situations in which these emerge, especially the categories of trato (deal) and contrato (contract), exploring what these meanings reveal about the world of the cantoria (singing) itself, as well as the universe of Pernambuco's Zona da Mata - a traditional sugar production region located between the Borborema plateau and the Atlantic Ocean in the northeast of Brazil. Conceived as a space of sociability for friends, neighbours and family, the brincadeira (play, diversion) is described here through the place occupied by money in its realization.
\end{abstract} Keywords: cantoria, sociabilities, ethnography, money, Pernambuco.

\section{Resumo}

Este artigo visa a apresentar os vários sentidos que as pessoas dão ao dinheiro na cantoria de pé-de-parede, que é uma reunião organizada em casa ou em um bar por um chefe de família ou pelo dono do estabelecimento comercial para ouvir versos improvisados por uma dupla de poetas-cantadores. Através do material etnográfico, foram examinadas as categorias empregadas para designar dinheiro e as situações em que elas emergiram, especialmente, as categorias trato e contrato, buscando compreender de que modo esses 
sentidos são reveladores do próprio mundo da cantoria e, também, do universo da chamada zona da mata pernambucana - território tradicional de produção açucareira, situado entre o planalto da Borborema e o Oceano Atlântico, na região nordeste do Brasil. Concebido aqui enquanto um espaço de sociabilidade de amigos, vizinhos e familiares, a brincadeira será descrita a partir do lugar que o dinheiro ocupa em sua realização.

Palavras-chave: cantoria, sociabilidades, etnografia, dinheiro, Pernambuco. 


\section{Money in the poetic universe of Pernambuco's Zona da Mata region}

Simone Silva

\section{Introduction}

In the Zona da Mata region of Pernambuco, the cantoria de pé-de-parede literally, 'foot-of-the-wall singing' - is a meeting organized at home or in a bar' by a family head or the owner of the commercial establishment to hear poetic verses, improvised by a duo of poet-singers. The pé-de-parede, called 'foot-of-the-wall' because the duo sing close to the wall, is held on Saturday evenings and Sunday afternoons, bringing together friends, family and neighbours, who are invited by the organizer and/or by the singer responsible for the event.

The process of holding the cantoria, or singing, is divided into three moments: the opening, in which the poets sing to thank the owner of the house/bar, in particular, for the support given to holding the event, and also to show off the duo's skill as singers; the praising, which consists of verses praising the name of all the adult guests present in the ambient, who, for their part, are expected to pay the poets for the laudatory verses; and finally the moment of the requests when the guests are allowed to ask for particular poetic modalities and songs. These three stages are interspersed by small interludes of about 10 to 15 minutes, during which verses may continue to be performed if a professional or amateur poet is present among the guests. In the region, the pé-de-parede, like other meetings based around dancing,

1 In the Zona da Mata, the bar is a commercial establishment which as well as selling drinks, supplies basic food items - rice, coffee, biscuits and sweets, for example - and sometimes cleaning products. Some smaller bars, sometimes only open at weekends or on days of brincadeira, just sell beer, soft drinks, sugar cane rum and sweets. In the region studied, most of the bars are annexed to the architectural structure of the proprietor's own house. 
singing or puppet theatres, for example, is considered to be a brincadeira, a play or diversion, which generally involves the uniting of friends and family in a ritual occasion marked by improvisation ${ }^{2}$.

The proposal to hold a cantoria may begin with an invitation of the owner of the house/bar or at the suggestion of the singer himself. Once both parties have agreed to hold the event, the 'deal' or trato is struck: that is, an agreement is reached between one of the singers from the duo and the owner of the bar and/or house. The venue where the pé-de-parede is held is considered a 'poetic ambient,' an ambiente de cantoria, by the singers. Each poet has his own particular ambients, which may be located in his current neighbourhood, in the place where he was raised or where he once worked, or in a region where he has family and/or friends who like poetry - the 'singing fans' (fãs de cantoria) as they are called. This ownership of ambients marks the agonistic character of the event, where there is always a local singer, the owner of the ambient - the one who 'closed the deal' (fechou o trato) - and the other singer, the invited partner, the singer from outside ${ }^{3}$.

The set of ambients as a whole form the extensive and complex geography of the cantoria through which, among other factors, each singer is legitimized as a professional. This poetic geography tends to expand as the singer acquires more years in the profession, although as he becomes elderly, even if he has already attained his peak as a singer and thereby become a professional of renown, the tendency is for his territory to reduce. This reduction is in part explained by physical tiredness.

2 Ever since the work of the folklorists, the native category brincadeira has become widely revived and proliferated in the historiographic, sociological and anthropological literature. A careful examination is still required, however, to deepen our understanding of the category itself and especially the relations reified by it. Analyzing the term summarily through the circumstantial characteristics of the cantoria, the objective of this ritual action may be very similar perhaps to that of the Mianmin, as described by Gardener (1983, cited in Strathern 2006): "Mianmin so act in a context of uncertainty about outcome, which makes every performance also an improvization. A successful outcome may be judged in the display itself, but this is only then to be judged by subsequent effects, in the long term affairs of the community" (Strathern 1987: 174). I allude to this interpretation of the Melanesian ritual primarily because of the characteristics marking this performance: improvisation and uncertainty that are similarly found at the basis of the idea of the brincadeira. In drawing this parallel, I obviously have no pretention of resolving the question. On the contrary, I wish to suggest that developing a general theory of the brincadeira may well involve the analysis of the native conception of improvisation, which marks relations, time and space in this universe.

3 The local versus outside opposition was once so central that cantoria in the nineteenth and early twentieth century was known as the desafio (challenge): the poets would duel for hours or even days for audiences of friends and family (Mota 1986). However the desafio is not unique to the rural world, nor exclusively Brazilian. Indigenous societies exist, for example, where women vie for their partner through forms of ritual challenge. In North Africa, quarrels at work or among neighbours are enough to mobilize men to engage in a poetic conflict. 
Today in Pernambuco, cantoria is propagated in events like pé-de-parede, town festivals, private performances organized during elections, radio programs, and competitions of duos of singers at regional and state festivals, held on large stages across the state. In addition cantoria is present in people's lives even when the ambient is not that of the brincadeira or the presentation of singers: this may be through the verses sung over the working day while cutting sugar cane, for example, or while preparing manioc flour, during household chores listening to cantoria programs on the radio, at birthday parties, or during events organized by the union to promote the wage demands of rural workers.

In this article I propose to analyze the cantoria through the place occupied by money in all its dimensions. I look to show how the innumerable meanings attributed to money inform a space in which equality and difference are complementary and, above all, demonstrate how money and intimacy operate simultaneously in the constitution of relations within this universe (Maurer 2006, Hart 2007, Zelizer 2009). Given the multiplicity of meanings acquired by money over the course of organizing and realizing the brincadeira, the ideas of Viviana Zelizer (1994) proved essential to analyzing the material discussed here. According to the author, money assumes particular meanings according to the social relations in which it is involved. Moreover these different meanings, she argues, are able to coexist in the same space and/or the same situation. I therefore pursued her proposal that any analysis of money must pay attention to the relative weight of its distinct functions (medium of exchange, store of value, unit of account, etc.), thinking about its circulation rather than dedicating exclusive attention to exchange, thereby enabling a deeper reflection on the time, space and relations of which money forms part (Maurer 2006). It is precisely this plurality of meanings attributed to money within a specific time and place that guides the reflection on the actions and relations personified by it.

Money has always been in short supply among rural workers of the Zona da Mata, including among the poets cited here, who prior to becoming guitar professionals worked in sugar cane cutting. Initially taken as ganho (render) or salário consentido (agreed salary) in payment for sugar plantation work, money revealed the employee's complete subordination and dependency on the employer, a relation typical of Brazilian plantations after the abolition of 
slavery. Following the conquest of civil rights laws back in the 1960s and thus access to the minimum wage, the rural population gained access to a range of goods in addition to basic food items, including mattresses, battery powered radios, clothing, and so on (Sigaud 1977).

"Then the governor, Doctor Miguel Arraes, came. He had been elected in 1962. Doctor Miguel Arraes gave workers the right to better wages, a higher salary and a Christmas bonus too. So it was during this period, in 1963 more or less, already a period of many struggles... the question of the Peasant Leagues already spreading through the sugar production zone... As I was working, I was able to receive a Christmas bonus. I decided to use it to buy a better guitar. So I went to the city, I went with a cousin of mine because I didn't know the city of Recife. I went to the city and bought a guitar and threaded the strings. I also bought clothing and a suit, I ordered a jacket and tie to be made. That's when I really began to be a singer." (Poet Beija-Flor 2005)

Pay is the most important aspect of work in the region. It is through the idiom of pay, for example, that people speak of agricultural activity, which is directly linked to the idea of wages. The money obtained in other activities - in singing or commerce, for instance - is considered the apurado or surplus. Wages are dedicated exclusively to food, a complete feira (literally: fair, market) ${ }^{4}$ of which comprises the following products in order of preference: manioc flour, beans, jerked beef, coffee and sugar, vegetable and fruits. The apurado, though, is a kind of complement to the purchase of food items. The Christmas bonus is dedicated to purchasing domestic goods and clothing, as attested in the above citation. In the universe of the cantoria, the apurado is the income on which the family depends to supplement the pensions of older poets, or a contract with the local council or work in the local food industries in the case of younger poets.

However, the apurado acquires a different set of meanings when we turn to examine the social relations woven in and through the ambient of the brincadeira. First and foremost, it enables and demarcates what I call the 'time of the cantoria,' which is delimited by sugar cane harvesting - that is, the period from September to January. It is a time that, like the concept

4 In Pernambuco fazer feira, 'doing a market,' means to purchase basic food products in large quantity. This purchase may be made monthly or weekly. 
itself, does not exist in any absolute form. Recalling the questions posed by Edmund Leach (1974: 204), we could say that we experience the time of cantoria “...but not with our senses. We don't see it, or touch it, or smell it, or taste it, or hear it. How then?" Its materialization, if we can describe it as such, emerges from the hiatus initiated with the start of winter, that is, through what Leach called the "oscillation between opposites," marked here by the times with and without work.

In the time of the cantoria emerges the trato (deal), which enables, as we shall see later, the apurado to exist as a debt, a commitment, friendship, paga (repayment), contribution and, in a borderline situation of conflict, even as payment. The trato makes explicit a relation constructed apart from money but not without it. It is the medium through which a deal is agreed in the name of consideration and friendship. The point is that, by itself, by analyzing the construction and dissemination of the trato, money acquires meanings beyond any narrowly economic definition. The use of money in the brincadeira is one of the elements in the production of hierarchies and differences, but at the same time it is money that reifies the solidarity between friends and family. It is the attempt to account for these various practices - which, for their part, reveal the form in which social relations are established and comprehended in the Zona da Mata region of Pernambuco - that will lead us into a detailed examination of money in the cantoria de pé-de-parede.

\section{Participating well in the cantoria}

The annual period for holding the cantoria, as observed earlier, is determined by the region's agricultural calendar: that is, by the period when the population will supposedly have enough money available to take part in the brincadeira, obtained from temporary contract work in sugar cane harvesting. After this contract has ended - from January to August, in other words - the circulation of money in the region is sharply reduced. If we compare the calendar for realizing the event to the 1960 s, there are no real changes. Since this time the second half of the year is when the cantorias are held. However Biu, an elderly man from a small town called Itaenga Lake who today puts cantoria in his home, was speaking one day about the conditions for realizing the brincadeira when he mentioned that "people never had money to pay the 
singer." Yet even so they turned up, unlike today when, he says, there is more money around.

"They arrived there and had to sit down and they would begin to perform the songs, verses, money appeared from nowhere” (Mrs. Iraci - Biu's wife. Itaenga Lake, 2007).

The native explanation reiterates what we saw earlier concerning the uses of wages and the apurado, that is, the money set aside to take part in the cantoria was not take directly from work pay. Biu, for example, during his youth in the 196os and 7os, would work on Saturdays in the sugar mill after being invited to a cantoria in order "to have the money to pay the singer." Today not only are many of these people on the urban peripheries living off odd jobs or the minimum wage, as the poet Beija-Flor told me, the opportunities for earning this 'extra' money have also shrunk. As a result today, even at the height of the harvest, the singer still needs to match the deal (trato) with the date on which people receive their fortnightly pay, that is, part of their salary.

The expectations that engender the ritual dimensions of the brincadeira are known by everyone who takes part in it: however, the use of the word 'obligation' is inadequate to the context given that everything in the cantoria is done in terms of the idea of 'free will.' The guests, for instance, say that go to the cantoria because they like it, while the poets claim that the repayment of the money paid by the owner of the house/bar recognizes all the efforts made by the latter. Like the gift the pé-de-parede is imbued with a selfless and voluntary character.

"They don't say because they already know; because if the singer sings, they have to pay." (Biu explaining that nobody in the region needs to be told that the singer must be paid)

The population of the meso-region of the Pernambuco Zona da Mata has participated since childhood in the various local brincadeiras, which implies a broad knowledge of the commitments and expectations entailed in these events. While still young, for example, people learn that honouring the invitation to a brincadeira is supremely important. In turn, however, whoever issues an invitation knows that this commitment is directly dependent on the financial situation of the person at the time of being invited. Everyone 
knows too that 'without money,' as I was told countless times, there is no way of participating well in the cantoria.

Participating well requires the money to purchase beer, sugar cane rum, soft drinks and sometimes snacks, as well as pay for transport, which is usually either a hired car or a motor-taxi, and, of course, provide the paga (repayment) during the praising and requests. All these demands, except for those with a fixed price like the car hire or motor-taxi service, become a means for the guest to display their virtues. Being generous, being a very distinct person, an excellent person, for example, which especially implies sharing beer or offering rum to others at your table, is seen as a positive quality. On the other hand, a mean person, someone who drinks, but does not contribute, or who fails to value the poet, is roundly condemned. Consequently, when an invitation is made, a series of questions come into play. This is why it is very important for those invited to assess whether they are really able to honour the invitation and take part and, if not, to tell the person who made the invitation the reason why.

Guest: Oh, I didn't go because of the money situation.

Mrs. Baixinha: Ah, but you could have gone, it's no problem. You should have gone. It wouldn't have been a problem because of the money.

Guest: Next time I'll go. (Feira Nova, February 2007)

Once the explanation has been given, the entire neighbourhood will learn the motive for the guest's absence. Here it is worth remembering the importance of being seen by other people, since some of the elements constituting prestige and honour emerge from this sociability. The poet himself should not display an excessive concern with the question of the apurado, though, otherwise the guests may think that he is in it just for the money - that is, he is a mercenary/self-seeking person. Furthermore he must adhere to the proper development of the cantoria, which implies completing its different stages in order: opening, praising and requests. This time is not determined by a set schedule, but a timing sensed in the unfolding of the brincadeira and negotiated with those present. Meeting these precepts implies a relation of trust between the guests and the owner of the house, on one hand, and the poet from the duo who is the 'owner of the deal' (dono do trato) on the other, without which the cantoria is rendered impossible. 


\section{The organization of the ambient}

The ambient of the cantoria is spatially organized in a way that demarcates the hierarchy of the guests in terms of their access to the poets and, above all, arranges the cantoria fans, including the members of the organizing family, according to their degree of knowledge of improvisation and poetic construction. However this spatial arrangement is not formal: the venues do not have a seating reservation system, for example. People know that elderly men sit in the first row and that they are the ones who pay the highest amount during the praising. In the row behind sit the older women, usually married, while the sides are occupied by younger women, and the last row of chairs by adult men and younger guests. The spatial location of a woman marks her status in the cantoria: economically dependent on the male figure of the father - occupying the front row - or her husband, seated in the back row.

Adult men, for their part, occupy the rear seats in accordance with their temporal familiarity with poetry. As they become older, they start being seen as specialists and thus move towards the front of the space. In many cantorias, the guests or even the poets themselves would point out an elderly senhor to me who knew a lot about poetry. He invariably sat on the bench closest to the duo of singers. This place in the first row was never described to me in terms of privilege, although over time one can identify its prominence in relation to the rest. It is these older men who are given preference when requests are answered, and they are the first to have their name praised during the praising phase.

The many young people present, though included in the brincadeira, do not even sit in the chairs: they remain standing at the back of the space. They also give the smallest amount to the plate. ${ }^{.}$Children, though their name is never sung, are allowed and indeed encouraged to sit in the chairs placed at the front next to the older men. This is one way in which adults gradually include children in this universe. Watching from this privileged spot, the children can accompany the interaction between the duo of poets

5 As we shall see later, the plate is the object used to leave the money given and/or paid for the verses sung. Its use is essential to the realization of this type of cantoria, and may only be substituted with a tray. The owner of the house/bar must line it with a tea towel or a table cloth before leaving it in the ambient where the cantoria will be performed. As far as I could tell, the exclusive use of this object relates to the native idea that the apurado/paga is not a form of charity, meaning that it cannot be replaced by saucers, hats or even pots and cups, all objects used at the end of the nineteenth century and the start of the twentieth by blind poets who sang for alms in the streets of Brazil's Northeast. Additionally I would venture that the exclusive use of plates relates to the wider meaning of the apurado, i.e. as an income supplement used to purchase food items. 


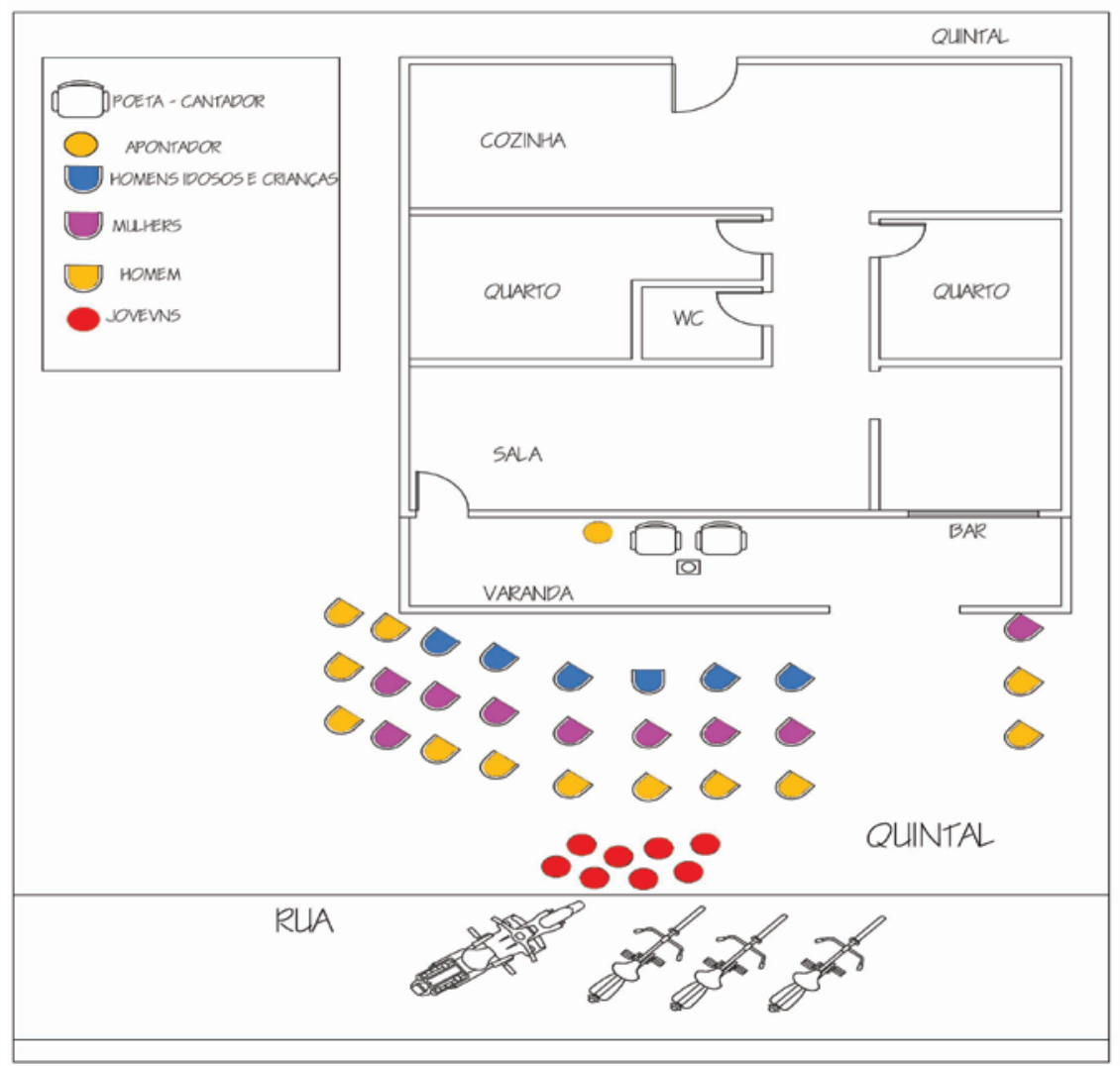

Floor plan of the cantoria

and the guests step-by-step. As soon as they begin to have their name sung, as the years pass, the boys, for example, begin the slow movement towards the front row - that is, from an initial condition of symbolic nonexistence to the privileged row.

\section{The insertion of the plate in the brincadeira}

The deal (trato) establishes the day when the brincadeira will be held, but not the time. People know that if taking place on a Saturday it will be at night, while a Sunday performance is always held in the afternoon. In the absence of an exact time for the event to start, people usually arrive gradually. The poets should not start the cantoria before most of the guests of the house/bar owner have arrived, although neither should they leave those already there waiting for too long. They may become distracted and lose the precise moment when 
the brincadeira begins. At the cantoria of Dona Maria, for example, Manoel Domingues, the owner of the deal, entered into a long conversation about the Lula government and the then candidate for the Pernambuco state government, Eduardo Campos. The guests present became irritated with the delay to the start of the event and one of them shouted in exasperation: "Hey Manoel, let it rest about Lula, man. Let's start the cantoria!" As soon as the complaint was voiced, the brincadeira began.

Just as there is a 'sensed time' for the start of the brincadeira, there is a specific way of announcing its various stages. The start of the praising, for instance - the first of the stages involving money - is mentioned in the final verses of the opening sextilha (six verses), indicating that the time of the paga (repayment) is approaching. At this moment, rather than referring to money or the apurado directly, the poets announce the subject by invoking terms like ganha-pão ('bread and butter') and boia-minha ('my grub'). These categories, in my view, are not explained by a reluctance to talk about money, which would be both an ethnocentric and mistaken conclusion, or by a mercantilist conception of acquisition. By substituting the term apurado with boia-minha, the poets highlight the bond of intimacy that the paga can establish between fans, poets and the owner of the bar/house. It is worth emphasizing that sharing or offering food in this region of Pernambuco, as in many other parts of Brazil, is a practice that delineates affection and friendship.

The mention of the boia-minha, announcing the start of the praising, is accompanied by references to other elements that form part of the ritual dimension of this stage, such as the lined plate. This object is responsible for mediating between the poet and the guests, who, on hearing their name mentioned in the verses, should head towards it. In the same cantoria mentioned earlier, while the poets were busy discussing President Lula and the Pernambuco state government, the house owner fetched the lined plate and placed it on one of the tables, next to where I was sitting. However the cantoria had not yet started. It should be noted that while preparing the space, the person may place a stool or some other support for the plate, but the object itself has to appear at a very precise moment. ${ }^{6}$

6 And this, in Brazil, is not confined to the cantoria. In candomble temple festivals, for instance, the plate where the payment to the orixá will be made is only taken to the ritual space after the first songs, clapping and dances (Baptista, José Renato, "Os deuses vendem quando dão: um estudo sobre os sentidos do dinheiro nas relações de troca no Candomblé”, MA dissertation, PPGAS Museu Nacional/UFRJ, Rio de Janeiro, 2006). 
Prior to Dona Maria's cantoria, I had never seen the presentation of the plate being anticipated. On this occasion, therefore, I failed to notice that the house owner's action had been too rushed, and that she had caused an awkward situation for the poets, especially for the owner of the deal. Manoel Domingues, very embarrassed, asked me: "Oh Simone, do me a favour, hide that plate there. Hide it out of the way. Early like that, it will startle everyone." Had Manoel left the plate on show before the cantoria had even started, this gesture would have shaken the trust built up over a ten-year period between the poet and his fregueses, or 'clients,' at Dona Maria's cantoria. The idea of the freguês relates to the bond of loyalty constructed over time. A person is not simply a freguesa de cantoria, but the freguesa of the cantoria of Poet $\mathrm{X}$, who becomes known by honouring the client every time that he or she attends. ${ }^{7}$

If the owner of the bar, for his part, forgets to bring the plate at the right time, the first verses of the praising are devoted to its solicitation, as can be seen in the stanza below, sung during the cantoria of Mr. Raimundinho:

I'm going to change my path

My road and my way

I began early last night

To arrive at the first light of day

It's time for Raimundinho

To hand me the lined tray

Eu vou mudar de caminho

De vereda e de estrada

Comecei cedo na noite

Para atender da madrugada

É hora de Raimundinho

Me dá a bandeja forrada

(The Portuguese version. Poet Severino Soares)

7 In the cantorias paid for by candidates during electoral campaigns, no plates are used during the events. In these cases the politician has sole responsibility for providing the apurado of the singers, which is taken as a payment, transforming the deal (trato) into a contract (contrato). In the region in question, poets often perform at birthday celebrations. There are no plates on such occasions either. 
In most cases the plate is brought by the owner of the bar/house, who leaves a banknote on it already as his contribution to the poet. This contribution, like everything else involved in the cantoria, does not have a previously stipulated monetary value. People know that it serves as a ceiling for the pagas (repayments) of the guests, hence its value, people told me, should act as a lure or attraction.

Simone: Can you start the tray with $\mathrm{R} \$ 1$, for example?

Biu Ambrósio (a bar owner): Ahh no, Simone. What would the others do afterwards? If he leaves one real, I'm going to leave one real too. I leave $\mathrm{R} \$$ 20.0o, only they [the singers] give it back to me later.

According to the poets, their handing back of the amount paid by the bar/house owner recognizes his work in organizing the event. His contribution is simultaneously a measure of value and the tie of kinship established between himself and the poet.

Throughout my 2006-07 stay accompanying the cantorias in the Zona da Mata, I did not see a single guest give a larger contribution than the amount offered by the owner of the cantoria. When the plate is started with ten reais, for example, people who have followed the singer for many years can very often be seen leaving the same amount. In the pé-de-parede, the more time a person has spent accompanying the singer's brincadeira, the higher the sum that he or she leaves is expected to be. For example, the elderly senhor nicknamed Cara de Gato has accompanied the cantorias of Heleno Fragoso for more than ten years; the singer esteems him greatly, hence it is very unlikely that he will make a contribution based on the lowest amount of the night, R\$ 2, for example. Zé Tapera, the oldest fan/client of Manoel Domingues at the cantoria of Mrs. Maria told me during one of our conversations that when he is ill, he finds the $\mathrm{R} \$ 5$ for the singer and asks someone to go to the brincadeira venue to deliver it. ${ }^{8}$

When the guest, despite following the poet's cantoria for a long time, is unable to contribute an appropriate amount, he or she will explain the situation to the singer:

8 In candomblé, the closer the relation between the child-of-saint and mother-of-saint, for example, the lower the amount charged should be (Baptista, op. cit.). 
Today I am vice-mayor [of the town of Paudalho], director of FETAPE, but I still sing in my municipality and my electors go there to leave a note for me in the bowl. One real. They say: "I can't give anymore, Senhor Beija-Flor, I just don't have it." When the cantoria is over, we drink some beers and rum and the money is spent right there and then. [laughs] (Poet Beija-Flor, Carpina, 2005)

Some workers will send an apology saying that they can't go due to a lack of money; they feel ashamed if the singer sings their name and they can't give even one real. It's a difficult situation, isn't it? (Beija-Flor, Carpina, 2005)

As well as the length of time accompanying the brincadeira and the closeness to the poet, expectations concerning the amounts given are also determined by what is known about the guest's financial status. The poet Sinésio Pereira, for example, once told me that he went to sing in the town of Camaragibe and the then mayor wanted to pay a very low amount for the praising made to him. The poet, very annoyed and upset, told him that he did not need to pay. The refusal was provoked not by the actual amount, but by the fact that everyone present knew that the guest was able to offer a much higher amount, hence the amount offered was seen as an insult. Even if the guest is not as famous as a mayor, everyone in this social universe is aware of everyone else's status. On various occasions I heard guests comment in a low voice that the poets should not sing the name of a particular person because he or she was 'smooth' (lisa) - in other words, he or she had no money to put in the plate.

Although there is no fixed sum, people know that complex poetic modalities - a decassilabo (decasyllable) for example - require a higher contribution. However the amount offered for a request must always be less than the amount given for the praising. The value attributed to a verse or song varies according to the ambient, the degree of intimacy, the relation's length of time and the expectations concerning the person invited. After various months in the field, I decided to make my first request for a verse at the cantoria of Mrs Brígida and Mr Baixinha, in Feira Nova. I placed the paper with the banknote on the plate, but I was immediately scolded by the daughter of the house owner, who told me that five reais was a very large amount. Trying to match the expectations of the singers concerning my payment, I had failed to taken into account that I would offend everyone else, since one cannot pay the same amount or more for a request as most of the guests have paid for their 
praisings. A repayment equal to the praising or higher is only acceptable in those situations where the guests organize a competition among themselves - for example, married against single people.

\section{The plate}

Once the plate is placed on the stool in front of the duo, the praising is initiated. ${ }^{9}$ The guests' names are invoked one-by-one, irrespective of the number of people at the brincadeira. The time between the improvised verse and the arrival of the banknote is short: as soon as the guest hears his or her name called out, the person heads to the plate with the banknote in hand. Sometimes I noticed that people would strive to hide the $\mathrm{R} \$ 2$ banknote in their hand when this was the amount they would give for their praising. Moreover, even if the brincadeira has many guests, which sometimes makes reaching the duo near impossible, the person whose name is sung must leave his or her banknote on the plate personally.

At one of the cantorias to which I went at the Melo ranch, in the town of Vitória de Santo Antão, the large number of people in the yard led to a list being compiled from which the guests were sung. At one point, the guest whose turn it was, finding it too difficult to reach the plate, had her contribution passed from hand to hand until it reached the pointer. Amid all the confusion it was no longer possible to identify the banknote's owner, so the pointer, waving the money in his hand, began to ask who had given the paga (repayment). The note was not placed on the plate until its owner was identified and announced out loud so that everyone could hear her name.

Through improvisation (improviso), the poet emphasizes certain social roles, insistently privileged in the verses, reaffirms ties of friendship and reinforces reputations. The person who emerges from this poetic contextualization is effectively placed on the plate, thus becoming part of the ambient of the brincadeira. Through the praising and consequently its payment, the guest is inserted into the context of the brincadeira and becomes authorized to intervene in the following stage. At the cantoria of Mrs. Maria, for example, I witnessed the moment when an elderly man, on being sung, was given his

9 During this phase, the duo receive help from a local person who performs the function of the pointer, that is, the person who will tell/recall the name of all the adults present at the cantoria. 
banknote by someone next to him. However, the person passed the money to him behind the chair so that nobody else would see. The affirmation of the person sung is legitimized by going to the plate. ${ }^{10}$

\section{PLATES}

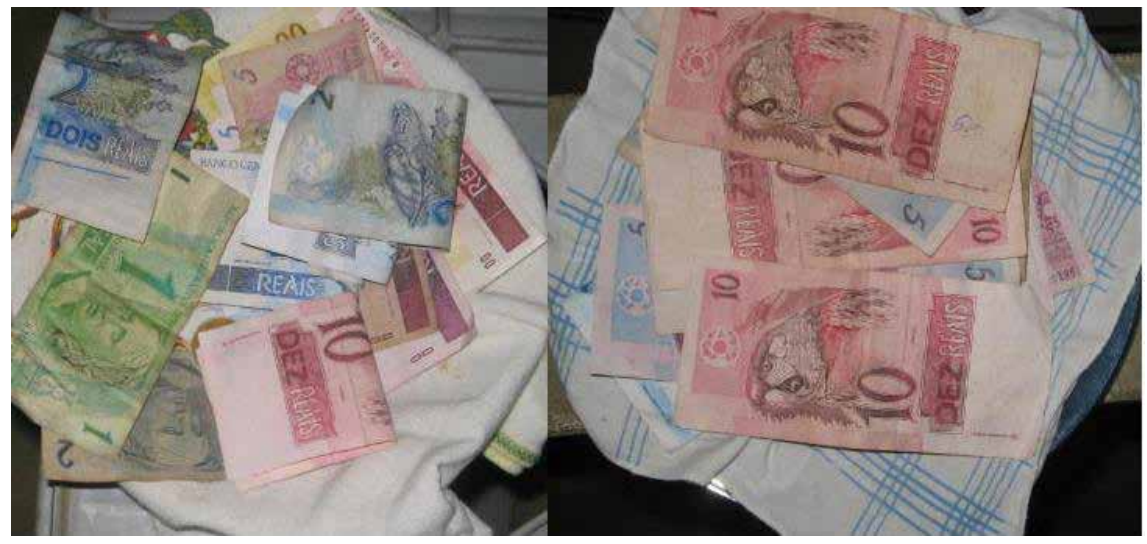

Photo 1: Cantorias at Biu Ambrósio's bar (2006)

Photo 2: Cantoria at the house of Mrs. Irene, at the Poço Grande ranch (2006).

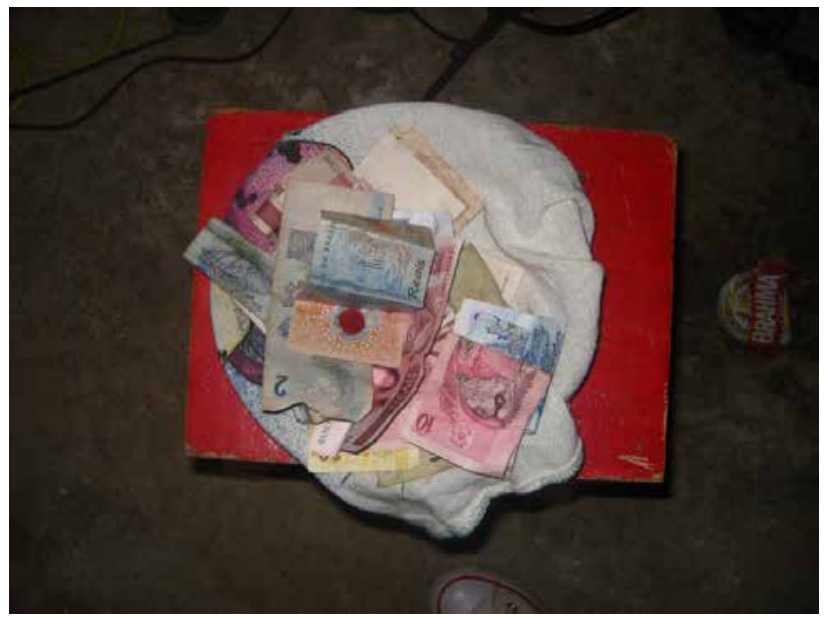

Photo 3: Cantoria of Mr. Raimundinho. Uruba Ranch, 2007.

10 This ritualization surrounding a payment that is made to third parties and mediated by a plate is not unique to the cantoria. In the ritual of the candomble feast, for example, an entire ritual procedure surrounds the act of placing money on the plate. The father-of-saint, prior to giving the money, which unlike the cantoria may also be in coins, performs a ritual through which the amount offered is passed around his body to wish health and prosperity: “...by placing the notes and coins on the plate these people believe themselves to be establishing a link with the orishá, which must be continually renewed, whether in other celebrations, or through offerings or ebós, or joining, and the obligations arising from these actions" (Baptista op.cit., p.111) 
Similarly to what happens in candomblé, for example, where the fatherof-saint is prohibited from touching the payment placed on the plate by the child-of-saint or client while still in their presence, the singer only touches with the banknotes when the brincadeira is over. Very often when a guest, on hearing their name sung, arrived with a twenty reais note wishing to contribute five or ten, the singer would ask me to give the person the change. If I had none on me, the task would fall to the pointer, but under no hypothesis did I see the singer or the guest him or herself touch the money. Oblivious to the proper protocol, I would very often muddle up all the banknotes while looking to give the guest his or her change. Heleno various times told me to re-arrange the plate so that the ten reais notes, for instance, were lying on top, as shown in the photo above.

My hypothesis is that no coins are used in the plate because of the relative weight played by the ambient in the very conception of the apurado. The place of the cantoria allows the money on the plate to be qualified by the guest as a contribution or as an apurado by the singer. For the professional poet, busking for money in the street, obtained from people to whom no relation has been established or even mediated, can be understood as 'charity.' Perhaps for this same reason, the plate being presented must be lined with a cloth, alluding to the family origin or a domestic environment. At the same time, the fact that coins are less prestigious and, above all, that the money on the plate expresses the praising and requests of the guests, probably means that they are shunned in relation to notes.

\section{Help and Contribution}

The banknotes placed in the plate at the moment of the praising are called by a series of names that, as mentioned above, vary according to the enunciator. The guests and the owner of the venue usually call them a contribution or help. However when a conflict emerges between them and the duo of poets, the monetary meaning is emphasized and, thus, help becomes called payment. Conflict, when it happens, tends to surface in the phase subsequent to the praising: the moment of the requests. ${ }^{11}$ Let's take an example. In the cantoria

11 A request is almost always made to honour a friend or relative present at the brincadeira. The poetic stanza or name of the song is written on a small piece of paper, along with the name of the honoured guest. 
of Mrs. Maria, one guest, who had already asked for the song "Amor de pai" (A father's love) decided to repeat the request, but with the demand that it was sung by the outside singer only. Faced with the guest's insistence, Sinésio refused to sing. He felt offended and said: “The moment that there's money on the plate, you have to sing." Sinésio, already annoyed, then replied: "In my own ambient, I don't repeat a song. I only repeated it here because I'm in Manoel's ambient." Trying to smooth over the situation, Manoel said that he would sing the song. After including the request, the duo paused for an interval during which they began to recall out loud the good cantorias they had performed at in the past. Sinésio mentioned one where he had earned two thousand reais. The guest who had protested earlier thought that Sinésio was comparing the ambients and argued that he should sing whatever the amount of money put on the plate. Eliane, Maria's daughter, told me that she had actually agreed with the guest because she too thought that Sinésio had been rude with his comment. Manoel, once again trying to calm people's nerves, asked the guest: "Lad, didn't I sing your request for a third time? Nobody here can leave saying that they paid but the request wasn't sung." The guest, still highly irritated with Sinésio, said to Manoel: “That's not how it works. If the request was paid, the singer has to sing. It's irrelevant whether the song has already been sung once, twice or three times. And don't explain it to me because I know what cantoria is."

The paga (repayment) of the request, unlike the paga of the praising, is emphasized by neither the guests nor the poets. It is only mentioned in situations like the one described earlier - that is, at a moment of misunderstanding between the audience and the poets or even among the guests themselves. At the same cantoria of Maria, for example, the guest who had been handed the money to pay for his own praising began to ask in a loud voice, already drunk, the duo to sing a décima (a ten verse song). Manoel, as the owner of the deal, told him that they would sing the request after he paid. The elderly man, clearly annoyed by Manoel Domingues's reply, began to shout: "But I already paid!" The other guests, by now fed up with all the shouting going on in the ambient, started laughing and said: "What did you pay, old goat? They gave you the money to pay for the praising. Keep quiet and don't disrupt the brincadeira, lad." The request was not sung and the discussion was closed. The detail concerning the loan of the money would not have been raised had the man not caused trouble. The guests made it clear that since the banknote 
on the plate was not his own - meaning that the ritual action surrounding his praising had been invalid ${ }^{12}$ - he was not authorized to interfere.

Returning to the guest's argument with the poet Sinésio Pereira, the man was offended by the poet's comment about the cantoria in which he had earned $\mathrm{R} \$ 2,000$ since the realization of a cantoria and its later qualification are elements that determine the prestige of the local area. This qualification is made in terms of good and weak, which relate on one hand to the quantity collected by the duo and, on the other, by the quality of the public - whether they were cantoria fans or not. Stating that a place always gives good cantorias emphasizes the knowledge and taste for poetry that the local people have and, above all, reveals the economic potential of the local area concerned. Biu Ambrósio, for example whose bar is recognized in Vitória de Santo Antão as a poet hot-spot, acknowledged that poets used to earn more in the past than today, but at the same time he argues that the present-day earnings in his own establishment are far from negligible:

Today there are occasions when its very weak. There are some poets who only come under contract. But today singing isn't the same as it was in the past, the money you can earn. You know? But those who come here to sing never waste their journey. I don't enter into contact, they come. Sunday cantigas can earn R\$ 200.oo. It's not much money but it's not nothing either. Sometimes it's less. It's all the same, two hundred, $R \$ 150, R \$ 100$. (Biu Ambrósio, Vitória, 2007)

This qualification concerning the apurado is not directly connected to the number of people present at the brincadeira. Some cantorias with more than 60 guests can earn less than one with 30 , as Manoel Domingues observed when he was speaking about a brincadeira full of people where he had performed: "Talk about hard-earned money?! Can you imagine how much singing we had to do to apurar [render] R \$16o,oo? The whole night, without stopping, until daylight.”

12 This specific situation allows us to return to Austin's speech act theory (1962: 55) on the following point: "Besides the uttering of the words of the so-called performative, a good many other things have as a general rule to be right and to go right if we are to be said to have happily brought off our action." The author claims that in cases of failed utterances, like the situation described above, it is not a question of classifying them as false, but as unhappy. Hence we can conclude that to utter the request for a verse means to have paid for the praising: if this does not occur then we fall into a situation in which the utterance is a mistake - that is, the procedure invoked is emptied of authority and thus the act is void and without effect. 


\section{Remuneration}

For the poets, the amount left on the plate is interpreted as an apurado, and only in very precise circumstances is it expressed in monetary terms, as stated by Biu Ambrósio. Sometimes when I provoked a conversation about the income obtained from cantorias, the poets would describe the value in terms of what it represented in purchases. According to Manoel Domingues, for example, the best brincadeira earned him three feiras (big market purchases) and enough left to buy a new suit.

The money from the cantoria guarantees a lot of things. It is not easy to earn, you sing all night, fight, get criticized, but you have to do everything necessary to earn this money, which is hard work. It helps domestically, it helps with household expenses, with buying gas bottles, water, clothing, shoes, because the singer travels a lot, he has to have clothes for travelling. He has to go about well-dressed. So the money from cantoria helps a lot with these things. (Poet Heleno Fragoso, 2007)

Simone: When you were at your peak, how much was a good cantiga? Poet Zé de Oliveira: Well, I don't remember. I remember that it was enough for a feira. A good cantiga would always be worth a feira with some left. But the actual amount I don't know.

But to understand the singularity of the apurado in relation to other kinds of money used in the region, we need to go beyond the merchandise expressed by it. Both the apurado and the salary are kinds of money described in terms of food items. However the meanings attributed to them retain important differences that need to be highlighted. The apurado contains the idea of difficulty, uncertainty and both frequent and situation-dependent negotiations, which to some extent diverge from the notion of right informing the category of salary. This allows us to return to the idea that the meanings, aside from relating to the kinds of goods purchased, contain essential properties for understanding the relations of which money forms part. Additionally it is worth remembering that although money renders everything calculable, the systems of calculation on which it depends are not always as simply numerical as we might imagine (Foster, cited in Maurer 2006).

Once the singularity of the meanings of the poet's remuneration have been identified, we still need to ask whether there is a - and if so what would 
be the - relative weight of different merchandise (purchased with the apurado and salary) in social relations. I already mentioned earlier that manioc flour, for example, is the most important product in the region's staple food basket. It is the local measure of value. Through it we can understand the native perception of their salaries, the identification of a financial crisis or even the notion of abundance. It is the indispensable product of the salary and likewise of any other supplementary income, such as the apurado. But there are goods - sugar can rum, for example - that are essential for the realization of a series of events, and which are bought exclusively with this additional income. Thinking about these singularities, then, I would ask what these specificities allow us to apprehend concerning the relations woven through the circulation of these goods. How may we, for example, describe the ritual of commensality in the house of a friend, emphasizing its differences when compared to the act of sharing a snack or drinking a shot of rum in the neighbour's brincadeira? I would say, for now, that these questions can help us advance, less through an understanding of a given expression as the representation of a way of life and more through an identification of the forms through which social relations are constructed.

\section{Final Considerations}

"If I observe of bridewealth exchanges which accompany a Melanesian marriage that the bride's parents are being paid for their feelings towards her, I am juxtaposing ideas which in the language I am using are normally antithetical. Emotion is not a commodity. Although I might try to wriggle out of the word 'paid,' it remains clear that I am describing as a transaction what is also an expression of relatedness..." Marilyn Strathern (2013:44)

Through the ethnographic material I have tried to show how purely economic relations exist side-by-side with the moral meanings attributed to money in the context of the relations between poet and guest, guest and guest, poet and owner of the house/bar. In this sense, we can speak neither of purely economic and selfish relations, nor, on the contrary, of purely selfless relations. The bread-and-butter, apurado, help or even the amount paid for a soft drink, beer or rum to be offered to the friends present, are parts of social relations and are as such hybrid, established in the pé-de-parede ambient. We 
have also seen that the quantity collected by the duo may grant the ambient a higher status as a venue good for singing, but it is also the ambient that determines that the money is not seen as charity. It does not dissolve ties, it reifies them. In this ambient, money may be the "material expression of abundance," but it may also express the taste for poetry, affection for the people present, and personal prestige. The fact that the money placed on the plate represents the guest means that, in the pé-de-parede, the poetic modalities, songs and contributions have no pre-set value. On the contrary they are meanings, as I have tried to show, based on relations of trust, the time of friendship, situation-based negotiations and expectations concerning the other.

To conclude, I would like to share with the reader a question underlying this text, which pervades the entire analysis and was sometimes challenging for me. This concerns the difficulty of speaking about money from an ethnographic perspective. The material studied here is part of a lengthy investment made in the field in order to think about the dynamics of sociability in rural spaces. Among the diverse aspects constituting the peasant condition - that is, its political, economic and social dimensions - my interest is in investigating their different ways of 'being related.' It is worth remembering that, in the Brazilian case at least, the peasant condition is informed by ways of life arising from very singular kinds of sociability. Consequently the social and moral condition of a given form of being related (sociabilities, family reproduction, kinship, neighbourhood, etc.) is linked to the production and reproduction of the peasant condition itself. This allows us to assert that its reproduction does not depend solely on political and economic reproduction, as has been emphasized for a long time by a large part of the bibliography on the topic. Hence I have tried to understand and explain questions from the Pernambuco sugar production region through the ambient spaces of poetry. This attempt is not consolidated by what we could call a supposed isolation from the spheres of social life, but by the native conception of ambient. Cantoria has proved a singular means for me to think through a series of questions - for example, its relation to the practice and meaning attributed to the exercise of local politics, the analysis of the sensory dimensions contained in the relation between the issuer and receiver of the narrative, about money, which in other domains would be less revealing about the social dynamic.

However anthropology's specific contribution towards understanding money - a phenomenon that is both a key element in classic generalizing 
interpretations and possesses widely different uses and meanings - elicited in me a series of uneasy questions. My central concern was not only to retain the native categories derived from anthropological research, but above all to avoid juxtaposing these with the ideas brought from my own universe concerning payment, help, remuneration, money, and other things. Looking back over the text, the reader may note, for example, that in many cases I have avoided using the verb and idea of 'buying' in preference for 'guaranteeing,' 'render' or even 'helping.' In native speech concerning the cantoria as a local event, the verb buy is used to express, for example, what is consumed in this ambient. So people use 'buy' to talk of beer, sweets for children, rum, etc. But in the situational narrative or even in the ambient, there is a significant change of idea when speaking, for example, of the cervejada (drinking beer with friends) or fazer uma farra, 'going on a binge' ("We went there, we drank all night, we had a binge"). The poet does not use the idea of 'buying' to refer to what he obtains from the remuneration of the cantoria. On the contrary, the apurado accrues or guarantees food, suits, a bottle of gas, etc. Neither does he 'earn money,' he collects it. The guests, meanwhile, do not pay, they give: the repayment or the help, or again, they put it on the tray. As we have seen, this ritual practice imbues the money from the cantoria with a state of purity, freeing it from pejorative connotations, such as the idea of charity.

As explained, the idea of payment - in the sense of the exchange of money, based on a monetary perspective - for an item or service is employed in situations of conflict and relative distance between the parties. When speaking generically of the obligations involved in taking part in the cantoria, people agree that "everyone should pay the singer." However when narrating a specific situation, the person says that "he gave help," "she made the repayment," "their contribution." Hence gradually discovering the way to speak of the monetary meanings of money, reconciling it with the local notion of intimacy, proved to be a task with valuable but simultaneously dangerous implications. As I have discussed, money assumes particular meanings according to the social relations in which it is involved. Furthermore, the ethnographic material presented demonstrates the coexistence of the diverse meanings that money can assume. Considering the proposal to examine in detail the relations of sociability involved in the circulation and notion of elements and objects that are intrinsic to it, we still need to reflect on the relative weight that each of the meanings imprints on them. Taking into 
consideration differences of scale, therefore, I would ask what the gains and risks are of the analysis when treating, for example, a measure in terms of 'intimacy'? How can an analysis of the relations between people and things be undertaken to identify values without jeopardizing our understanding of the forms of constructing social relations? These are the kinds of questions that we need to develop.

To conclude I wish to return to the question of the lined plate. In the part of the year without cantoria, the professional poets of the Pernambuco Zona da Mata refused to busk in the streets or head for the coast to sing arbitrarily. As already mentioned, the street is an impersonal space in which the money given to the poet can easily be understood as charity. In an ethnographic study that I conducted during the 2012 electoral campaign, in which one of the poets with whom I work was running for office as a local councillor, the street similarly proved to be an improper place for the elector to negotiate his or her vote with the candidate. Those who insist on approaching the candidate in the street to ask for whatever he or she wants, especially money, is seen to be 'untrustworthy.' The space for negotiation is the house. Consequently it is not the objects involved in a negotiation that are responsible for its state of purity or impurity, but the place where it takes place. In other words, with the exception of money, the elector may request everything from a food basket to a mattress. The latter will not make him or her seem untrustworthy. But if done in the street, everyone will certainly see the person as 'opportunist.' In the cantoria, it is the lined plate that leads to money assuming a particular dimension, distancing it from the viewpoint of pure exchange. We could say that the plate sustains a metonymic relation with the house, which, through the contiguity of meanings between them, reveals the money to be personal. Hence the lined plate, that simple and apparently utilitarian object, located in front of the audience, configures the most complex aspect of the relation: the fact that money and ties of intimacy operate simultaneously in the construction of the social relations of this universe.

Translated from the Portuguese by David Rodgers

Received October $24^{\text {th }}$ 2013, approved December $12^{\text {th }} 2013$ 


\section{Bibliography}

ARANTES, Antônio Augusto. 1982. O trabalho e a fala. Campinas: Editora Kairós / FUNCAMP.

AZEVEDO, Débora Silva de. 2011. "Nas redes dos donos da brincadeira: um estudo do mamulengo da zona da mata pernambucana". MA Dissertation, Postgraduate Program in Social Sciences in Development, Agriculture and Society/CPDA/ UFRRJ, Rio de Janeiro.

AUSTIN, J.L. 1962. How to do things with words. Harvard: President and Fellows of Harvard College.

AYALA, Maria Ignez Novais. 1988. No arranco do grito.(aspectos da cantoria nordestina). São Paulo/ João Pessoa: Ática/ UFPB.

BAPTISTA, José Renato de Carvalho. 2006. Os deuses vendem quando dão: um estudo sobre os sentidos do dinheiro nas relações de troca no Candomblé. MA Dissertation, PPGAS/Museu Nacional/UFRJ, Rio de Janeiro.

BLOCH, Maurice. 1994. "Les usages de l'argent”. Terrain. (23): 5-10.

CAMARGO, Aspásia. 1981. "A questão agrária: crise de poder e reformas de base (1930-1964)”. In: Boris Fausto (ed.), O Brasil Republicano. Coleção História geral da civilização brasileira. Tomo III, 3o volume (1930-1964), São Paulo: Difel, pp. 121-224.

CARNEIRO, Renato Campos. 1971. "Folhetos populares na zona do açúcar de Pernambuco.” In: Cavalcante Proença et alli. (eds), Literatura de cordel. São Paulo: ECA/USP, pp.167-210.

CASCUDO, Luis de Câmara. 1939. Vaqueiros e cantadores. Porto Alegre: Edição da Livraria do Globo.

DOUGLAS, Mary. Pureza e perigo. Lisboa: Edições 70.

ELIAS, N. and DUNNING, Eric. 1992. A busca da excitação. Translation: Maria Manuela Almeida e Silva. Lisbon: DIFEL.

GARCIA Júnior, Afrânio Raul. 1989. O Sul: caminho do roçado. Estratégias de reprodução camponesa e transformação social. São Paulo/ Brasília: Editora Marco Zero/ Editora Universidade de Brasília.

GODOI, Emilia Pietrafesa de et alli. (eds.), 2009. Diversidade do campesinato: expressões e categorias. Vol. I. Construções identitárias e sociabilidades. São Paulo: Editora UNESP.

GOODY, Jack. 1987. The interface between the written and the oral. Cambridge: Cambridge University Press.

HART, Keith. 2007. "Money is always personal and impersonal”. Anthropology 
Today, 23, (5):12-16.

LEACH, Edmund.1974. Repensando a antropologia. São Paulo: Editora Perspectiva.

LEITE LOPES. José Sérgio. 1976. O vapor do diabo. O trabalho dos operários do açúcar. Rio de Janeiro: Paz e Terra.

MARX, Karl. 1988. O capital: crítica da economia política. Os economistas. São Paulo: Nova Cultural.

MAURER, Bill. 2006. “The anthropology of money”. The Annual Review of Anthropology, 35:15-36.

MAUSS, Marcel. 1979. “A prece”. In: Roberto Cardoso de Oliveira (ed.), Marcel Mauss: Antropologia. São Paulo: Ática, pp.102-146.

MAUSS, Marcel. 2003. "Ensaio sobre a dádiva. Forma e razão da troca nas sociedades arcaicas”. Sociologia e Antropologia. São Paulo: Cosac \& Naif, pp.185-314.

NEIBURG, Federico. 2007. "As moedas doentes, os números públicos e a antropologia do dinheiro". Mana. Estudos de Antropologia Social, 13(1):119152.

OSÓRIO, Patrícia Silva. 2006. “Cantoria de pé-de-parede: a atualização da cantoria nordestina em Brasília”. Cadernos de Campo, 14/15: 65-81.

PALMEIRA, Moacir. 1977. "Casa e trabalho: notas sobre as relações sociais na plantation tradicional”. Contraponto, II(2):103-114.

PALMEIRA, Moacir; HEREDIA, Beatriz. 1995. “Os comícios e a política de facções”. Anuário Antropológico. 94:31-94.

PEREZ, Léa et alli. 2012. Festa como perspectiva e em perspectiva. FAPERJ/ Garamond Universitária.

RADCLIFFE-BROWN,A.R. 1973. "Parentescos por brincadeira”. In: Estrutura e função na sociedade primitiva. Petrópolis: Editora Vozes, pp.115-146.

SAUTCHUK, João Miguel Manzolillo. 2009. A prática do improviso: prática e habilidade no repente nordestino. $\mathrm{PhD}$ thesis. Postgraduate Program in Social Anthropology, Brasília, University of Brasília.

SIGAUD, Lygia. 2005. "Se eu soubesse: quando os dons tornam-se mercadorias". Paper presented at the Internacional Colloquium Quantificação e Temporalidade: perspectivas etnográficas sobre a economia. Rio de Janeiro: Museu Nacional/UFRJ. Mimeo.

SIGAUD, Lygia. 1999. "As vicissitudes do "Ensaio sobre o dom”". Mana. Estudos de Antropologia Social, 5(2): 89-123. 
SIGAUD, Lygia. 1979. Os clandestinos e os direitos. Estudo sobre trabalhadores da cana - de - açúcar de Pernambuco. São Paulo: Duas Cidades.

SIGAUD, Lygia. 1977. "Expropriação camponesa e trabalho assalariado em áreas de plantation e fronteira". In: Moacir Gracindo Soares Palmeira (ed.), Projeto emprego e mudança sócio-econômica no Nordeste. Research Report. Rio de Janeiro: Museu Nacional/ UFRJ. Mimeo.

SIGAUD, Lygia. 1977. "A percepção do salário entre os trabalhadores rurais". In: Jaime Pinsky (ed.), Capital e trabalho no campo. São Paulo: Editora HUCITEC. pp. 49-67.

SILVA, Simone. 2010. "A gente não esquece porque sabe o que vai dizer" Um estudo etnográfico da cantoria de pé-de-parede da zona da mata de Pernambuco. $\mathrm{PhD}$ thesis, PPGAS, Museu Nacional/UFRJ, Rio de Janeiro.

STRATHERN, Marylin. 2006. O gênero da dádiva: problemas com as mulheres e problemas com a sociedade na Melanésia. Campinas: Editora da Unicamp.

STRATHERN, Marylin. 1987. "Out of context: the persuasive fictions of anthropology”. Current Anthropology, 28(3): 251-281

ZELIZER, Viviana. 2009. "Dualidades perigosas". Mana. Estudos de Antropologia Social, 15(1): 237-256.

ZELIZER, Viviana. 1997. The social meaning of money. Pin money, paychecks, poor relief, and other currencies. New Jersey: Princeton University Press. 